Ethiopian Journal of Environmental Studies \& Management 10(1): 11 - 21, 2017.

ISSN:1998-0507

doi: http://dx.doi.org/10.4314/ejesm.v10i1.2

Submitted: September 14, 2016

Accepted: January 18, 2017

\title{
IMPLICATIONS OF CHANGING LAND USES ON PHYSICAL ENVIRONMENT IN CALABAR MUNICIPALITY, CROSS RIVER STATE, NIGERIA
}

*UMOREN, V.E. ${ }^{1}$ AND UDOUDOH, F. P. ${ }^{2}$

${ }^{1}$ Departments of Urban/Regional Planning, Faculty of Environmental Studies, University of Uyo, Akwa Ibom State, Nigeria

${ }^{2}$ Department of Estate Management, Faculty of Environmental Studies, University of Uyo, Akwa Ibom State, Nigeria

\begin{abstract}
The rapid rate of changing land use in urban areas has reached alarming proportions. The changes are observable along major transport routes particularly within the central business districts (CBD). The aim of this study was to assess the attendant problems as well as implications of changing land uses on physical environment in Calabar Municipality, the capital city of Cross River State in Nigeria. The study adopted the systematic random sampling technique in the administration of questionnaires. The sample size for this study was obtained from the total population number of residential, commercial and public buildings in the area which was 1,847. A sample of 461 was adopted for the study. Descriptive statistics was employed in the analysis of the data. The study revealed the factors influencing changing landuses in the area to include increase commercial activities, physical deterioration of the buildings, upgrading and accessibility of roads etc, it also revealed problems noticed along roads as a result of changing landuse and implication of changing landuse in the study area. The study recommends that the embarking on landuse and transportation studies, monitoring of landuses in the study area and others. This when done will bring about proper development.
\end{abstract}

Key Words: Land use, Property values, Parking space, Major roads, Traffic congestion

\section{Introduction}

Different persons and communities see land in various perspectives depending on the circumstances and contexts which it is being used and considered. Umeh (1983) discusses land physically, spiritually, socio-politically and as an abstract object; whereas Barlowe (1978) sees land as a natural and consumable object, as a space, capital and as a factor of production use for attainment of economic goals. Land has also been viewed as an object created by law and as an economic property, hence a potent source of revenue for individuals, communities, corporate bodies, and states. Land is bought and used for diverse purposes including residential, commercial and industrial in the urban centres. Residential Land uses include the various houses that are built for the occupation of individuals and members of the family. It may be tenement houses, flats, bungalows,

*Corresponding Author: Umoren, V.E.

Email: vicmoor2000@yahoo.com 
storey blocks and maissonnettes. It is classified into high density, medium and low density residential areas within a residential estate. It may be privately or publicly built usually the largest land use within the urban areas. Commercial Land uses include shops and offices occupied for the purpose of carrying on any trade or profession in the expectation of profits. They may be converted or purpose-built like the shopping Centers or UAC Trading Company found in Nigerian major cities. It also includes the traditional market, lockup market complexes, motels and hotels, cinema houses, petrol/filling stations, supermarkets, etc; while Industrial land uses include factories where production, processing and storing of raw materials and finished goods are done. The range of properties to be considered is extensive and varies from shops to residential properties converted for use as storage or for factory purposes, to well constructed and lighted up-to-date promises with many amenities. The light industries may be located within the residential areas while heavy industrial outlet noted for industrial pollution are located at out-skirt of the city such as petro-chemical industries and refineries.

The Building Act of Great Britain (2004) defines change in use as a process where a change in a building will require an upgrading to certain systems and elements. For example, a residential building may be converted into a shopping complex or a garage into an eating room or a photographic studio. This is so as property development is dynamic, a continuous affairs which come by way of expansion, alteration, renovation or outright conversion of former use. As An (2005) put it, land redevelopment projects lead to significant change in residential neighbourhoods and generate significant spillover effects to another area. Oduwaye (2013) noted that in Lagos Metropolis, land use changes have been sporadic due to improper monitoring of the changing structure and widespread urbanization which has resulted to a change in land use structure from a simple pattern to a complex one.

Several scholars have argued that changes in land use are brought about by various factors. Lee (1974) lists such factors to include the aging of the residents, the growth and maturity of their children which eventually cause a turnover in the ownership of housing. Other contributing factors are the physical aging of the building structures leading to obsolescence and eventual abandonment. Winger (1977) has also shown that certain technological changes, good transportation network, income and population growth account for the movement of residential area inwards into the city or changing residential location from the $\mathrm{CBD}$ to the suburb. By implication, commercial activities move to the major roads or CBD where there are potentials for easy transportation, attraction to customers and required space for expansion. Some other factors that influence change in the use of land include social, economic, institutional, etc. Adebayo (2009) stated that for economic reasons, land and buildings will continue to change in use from a lower order to a higher status in order to attain optimal use. Hill (1989) enumerated the factors that cause changes in land use to include personal choice, legislation, government policies and plans, decision of developers or transportation entrepreneurs, the nature of the land itself and the availability of technology to develop the land. Turner and Meyer (1991) 
listed the possible factors that drive land use change to include population, level of affluence, technology, political economy, political structure, attitude and values; while Lambin et al. (2003) pointed out that many of the land use changes that occur are due to ill-defined policies and weak institutional enforcement.

Lean (1966) had earlier argued that as city grows, position of greater accessibility and complimentary activities may divide from the main rental areas, when this happen peak and ribbing development appears. In 1969, he also argued that business requiring office accommodation will in many cases be able to pay higher rents and compete for strategic position from alternative uses. Garrison and Deakin (1992) enumerated factors that give land value as transportation, land use location, topography and land features such as views, building type, quality and size. On the other hand, Ball et al (1998) argue that when land prices rises, land owners release land for commercial development. Positive economic activities generate demand for stronger activities to take over weaker economic landuses. According to Egbenta (2011), developers take these market signals and begin to develop, and other investors are willing to fund the development or purchase the complementary development. The peaks are the higher land values which reflect clusters of complementarities activities within the general position of greater accessibility.

The American Institute of Real Estate Appraisal (1994) observes that the highest and best use of a property reflects the market perception of its present value. The highest and best use of any particular site is often subject to change. Like the concept of use-capacity, it can shift with changes in the quality of the land resources, technology, political situation and urban demand. The basic factors that determine the highest and best use of any piece of land being topography, availability of technology, finance, legal framework, expected profit margins and the state of the economy. When the government decides to create an urban centre from a rural settlement, it automatically compels the residents of the community that was erstwhile agrarian to shift to other uses, such as residential and commercial land use. This is how virgin land traditionally used for agricultural purposes are converted to residential use as the community grows in population. In most towns, it is observed that the city centres where growth started outwardly gradually shift from residential uses to commercial uses. Udoudoh (2016) noted that where this growth is steady, there is a tendency for each site to be developed to its highest and best use through the competition of entrepreneurs who have various plans for the use of the land in different combinations with the other factors of production. It is through this process that the land use pattern of the city is developed.

Egbenta (2011) studied land use changes in Enugu urban and noted that there is rapid spread of land use changes along Okpara Avenue, Ogui Road, Market Road, Abalaliki Road, Zik Avenue and Agbani Road. He concluded that since there are no more spaces within the builtup areas of the city to accommodate expansion, the burden now fall on the residential land use that are purchased to change their existing land uses.

The American Institution of Real Estate Appraisal (1994) defines value as the highest price estimated in monetary 
terms which a property will bring if exposed for sale in the open market allowing a reasonable time to find a purchaser who buys with knowledge of all the uses to which it is adopted and for which it is capable of being use. Value can be seen as a product or a result of interaction of market forces of demand and supply of any particular commodity at any particular place and time. Demand here goes beyond the mere desire to possess as such desire can have no influence upon market value except when match against the willingness and ability to perfect such payment. This is also affected by the readiness of the productive owner to transfer such property to an intending demander at offered price and time.

Valuers are primarily interested in the open value. Others like quantity surveyors or accountants are interested in cost theory of value or historical cost. The use of cost for asset or plant and machinery valuation is an attempt in this direction. The concept of value to a valuer has nothing to do with social or esthetic value. Value is not intrinsic but results from estimates, which are subject made by willing and able purchasers of an interest where benefit or satisfaction will be achieved. Different values can be placed on a given piece of property at the same time. This becomes possible as opinions of values are estimates made with diverse background, and necessary adjustments made, if any, to reflect the state of the property and the situation at hand.

Three concepts of value have been identified, namely, economic, open market and cost value concepts. For the purpose of this research, our concern centres on open market value which is defined by the Royal Institute of Chartered Surveyors (RICS) Appraisal and Valuation Manual
(1996) as the estimated amount for which an asset should exchange on the date of valuation between a willing seller in an arm-length transaction after proper marketing wherein the parties had each acted knowledgeably, prudently and without compulsion. This is why market price and market value are not always the same. RICS has defined open market value as the best price at which an interest in a property might reasonably be expected to be sold to private treaty at the date of valuation assuming:

a willing seller;

a reasonable period within which to negotiate the sale, taking into account the nature of property and the state of the market;

values will remain the same throughout the period;

the property will be exposed freely to the market; and

no amount is to be taken off an additional bid by a special purchaser.

It is the responsibility of a valuer to determine the open market value (capital or rental) of land and/or building. To assess the value correctly, the knowledge of the purpose for which the valuation is required, the intentions and circumstance of the client or employers on whose behalf the valuation is prepared are needed. This is in addition to the physical inspection and taking of measurements of the valued property by the consulting valuer. A property has no value if it has no utility. The ability of a property to satisfy man's needs and desires together with its degree of scarcity and utility compared with others makes man ascribes value to it. It is this man's collective desire for property that gives rise to value. According to Udoudoh et al. (2011), property value therefore is the worth of the assets, value created on land, buildings and other 
development thereon. In Calabar municipality there is an increase in changes in original landuse to new development which has consequences on property values. It is a common development where residential landuses give way for commercial development.

This paper focused on the implications of changing land uses on property values in Calabar, an ancient city in South Eastern part of Nigeria. The objectives of the study are to:

(i) examine the factors that influence changing land use in the study area;

(ii) examine the implications of changing land use on property values in the study area.

\section{Study Area}

Calabar is one of the oldest urban centres in Eastern Nigeria. Apart from being a Local Government Area and the capital of Cross River State, it also plays the political role as the headquarters of the Southern Senatorial District. Calabar developed as a river port into a commercial centre. Calabar Municipality lies between Latitude $4^{\circ} 57^{\prime}$ and $5^{\circ} 04^{\prime}$ North of the Equator and Longitude $8^{\circ} 18^{\prime}$ and $8^{\circ} 24^{\prime}$ East of the Greenwich Meridian. The area is bounded in the North West by Odukpani
Local Government Area and Calabar River, in the East by Akpabuyo Local Government Area and the Southern shores are bounded by the Calabar South Local Government Area (Figure 1). Calabar gained prominence during the early part of the $17^{\text {th }}$ century. This was largely due to the increasing trade relations between the African tribes - the Efiks and Ibibios (Ima, 2008). Calabar Municipality has experienced economic progress through the avalanche of commercial and socioeconomic activities and these have brought about tremendous growth in several aspects of urban services to meet the challenges of a state capital. The construction and rehabilitation of roads have opened up land in Calabar Municipality thereby allowing for competition of road space among road users as private companies, retail stores, hotels, service industries and banks aggregate to take the advantage offered by these good roads. Calabar Municipality has witnessed increase in the flow of traffic. Most of the major roads in the state now experience road traffic related problems such as parking problems, traffic congestion and road traffic crashes. 


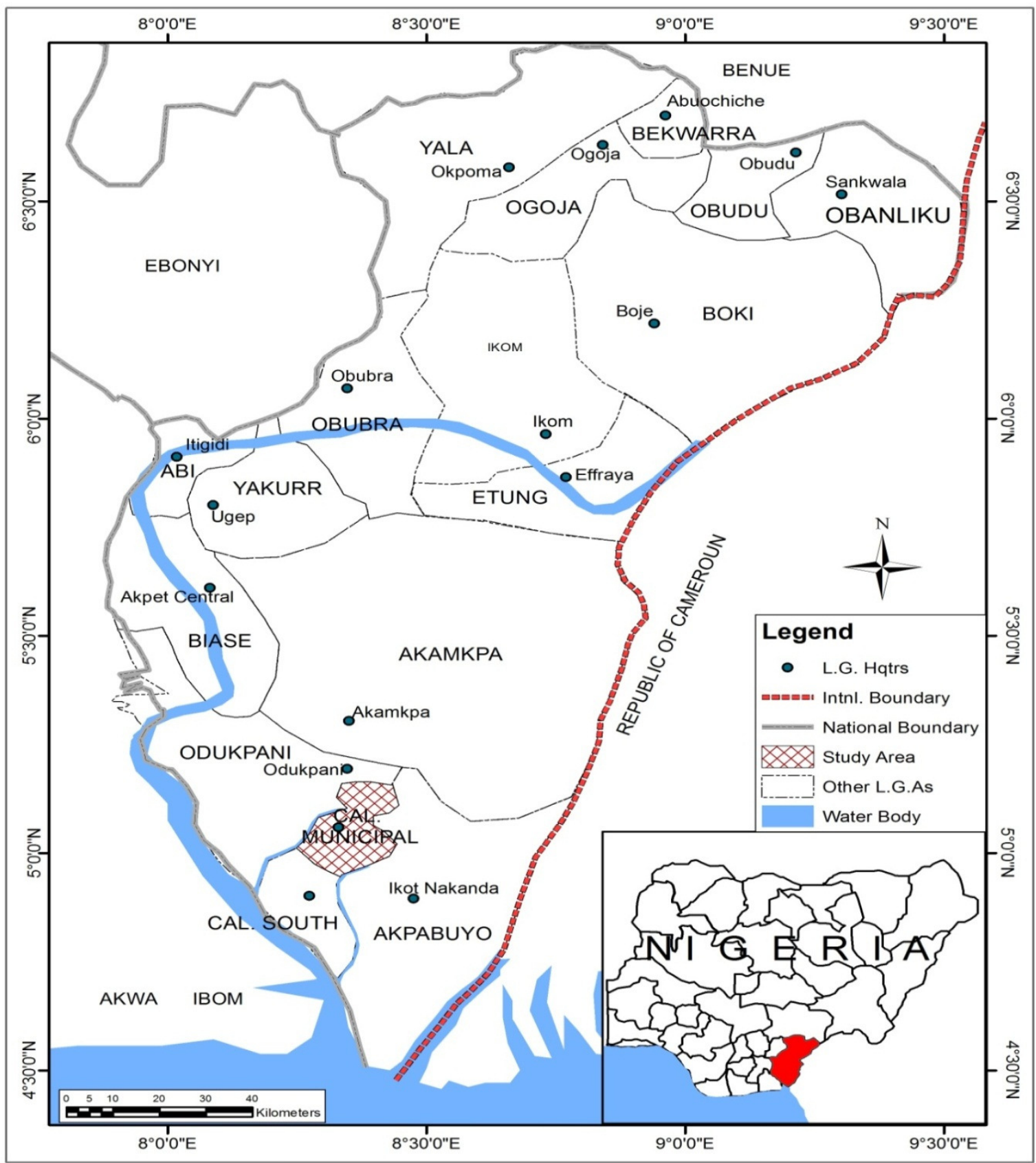

Figure 1: Calabar Municipality on the map of Cross River State

Source: GIS Department, Ministry of Lands and Town Planning, Calabar, Cross River State

\section{Materials and Methods}

Data for the study was collected through field survey. The sample size for this study was obtained from the population (total number) of residential commercial and public buildings along the sampled roads in the study area which was 1,847 .

In order to determine the sample size that was appropriate for the study, the 
Bartlett, Kotrlik and Higgins (2001) model was adopted. Based on the model the sample size for the population of residential, commercial and public buildings along the sample roads was 461 . The study adopted the systematic random sampling technique in the administration of questionnaires. Respondents were systematically selected along the major roads until the required sample was obtained. In each of the major roads, respondents were selected from every $4^{\text {th }}$ building. The skipping range was determined by dividing the total number of buildings along the sampled roads by the sample size (1,847/461). Consequently, the questionnaire was administered to the head of households in each of the building. Descriptive statistics was used to analyse the data. The descriptive statistics made use of frequencies and percentages, to analyse and describe the data obtained through questionnaire administration.

\section{Results and Discussion}

Table 1 revealed that out of a total of 426 respondents which their opinions were sought, 76 of which representing $17 \%$ of the sampled population indicated that increase in commercial activities is the major cause of change in land use in Calabar Municipality. The second reason given was physical deterioration of the affected buildings as shown by 56 respondents representing $13 \%$ of the sampled population. The third reason was identified as upgrading of accessed roads to the buildings as shown by 48 respondents representing $11 \%$ of the sampled population. This wasclosely followed by improvement in other neighbourhood facilities as indicated by 46 respondents representing $11 \%$ of the sampled population. The other adjudged serious reasons were change in family status and government policy which noted by 44 and 42 respondents representing $10 \%$ and also $10 \%$ respectively.

Table 1: Factors influencing changing land use in the study area

\begin{tabular}{|c|c|c|c|c|}
\hline $\mathrm{S} / \mathrm{N}$ & FACTORS & $\begin{array}{l}\text { NO. OF } \\
\text { RESPONDENTS }\end{array}$ & $\begin{array}{l}\text { PERCENTAGE } \\
\text { OF } \\
\text { RESPONDENTS }\end{array}$ & RANKING \\
\hline 1 & Increase in commercial activities & 76 & 17 & $1^{\mathrm{st}}$ \\
\hline 2 & Change in family status & 44 & 10 & $5^{\text {th }}$ \\
\hline 3 & $\begin{array}{l}\text { Upgrading and Accessibility of } \\
\text { Roads }\end{array}$ & 48 & 11 & $3^{\text {rd }}$ \\
\hline 4 & $\begin{array}{l}\text { Improvement in other } \\
\text { Neighbourhood Facilities }\end{array}$ & 46 & 11 & $4^{\text {th }}$ \\
\hline 5 & $\begin{array}{l}\text { Physical deterioration of the } \\
\text { Buildings }\end{array}$ & 56 & 13 & $2^{\text {nd }}$ \\
\hline 6 & Government Policy & 42 & 10 & $6^{\text {th }}$ \\
\hline 7 & $\begin{array}{l}\text { Attitude and Taste of property } \\
\text { owner }\end{array}$ & 26 & 6 & $9^{\text {th }}$ \\
\hline 8 & Profit Maximization & 34 & 8 & $7^{\text {th }}$ \\
\hline 9 & Poor Neighbours Relationship & 24 & 6 & $10^{\text {th }}$ \\
\hline \multirow[t]{2}{*}{10} & Change of working Environment & 30 & 7 & $8^{\text {th }}$ \\
\hline & TOTAL & 426 & 100 & \\
\hline
\end{tabular}


The problems associated with changing land use along transport routes in the study area are presented on Table 2. It showed that a total of 147 respondents representing $35 \%$ of the sampled population agreed that traffic congestion was one of the major problems noticed along roads as a result of changing land use. Also as many as 140 respondents representing 33\% noted that parking problems was one of the major problems noticed along roads as a result of changing land use in the study area. In the same manner, 65 respondents representing
$15 \%$ noted that noise pollution was one of the major problems noticed along roads as a result of changing land use. Only 44 respondents representing $10 \%$ of the sampled population observed that accident was one of the problems noticed along roads as a result of changing land use in the study area, while 30 respondents representing $\quad 7 \%$ identified indiscriminate/haphazard display of bill boards/signposts as a problems noticed along roads as a result of changing land use in the study area.

Table 2: Problems noticed along roads as a result of changing land use

\begin{tabular}{lll}
\hline Problems & Frequency & Percentage (\%) \\
\hline Traffic Congestion & 147 & 35 \\
Parking Problems & 140 & 33 \\
Noise Pollution & 65 & 15 \\
Accident & 44 & 10 \\
Indiscriminate/haphazard display of bill boards/signposts & 30 & 7 \\
Total & 426 & 100 \\
\hline
\end{tabular}

Table 3 revealed the implications of changing land use on roads in the study area. From our field survey, a total of 152 respondents representing $36 \%$ of the sampled population were of the opinion that the change in land use brings about increase in traffic problems; while 143 respondents representing $34 \%$ were of the opinion that the change in land use leads to decrease in residential housing stock along the major roads. Also, 78 respondents representing $18 \%$ noted that the change leads to increase in rental value of land uses in the neighbourhood while 53 respondents representing $12 \%$ of the respondents observed that the change result in deterioration in poor quality of the environment. The implications of changing land use on roads in the study area include traffic, housing and economic implications. The traffic implications include traffic congestion, delay in journey, parking problems and increase in traffic noise which constitutes a serious nuisance. On the other hand, the implication of changing land use along roads on residential housing in the study area is the succession of residential land use by other uses, hence shortage in total housing stock. It also has economic implications, competition among land users will ensue which result in increase in land value. The competition will result to escalating rental value of land uses from time to time thereby making the rental value of these land uses difficult to predict. 
Table 3: Implications of changing land use in the study area

\begin{tabular}{lll}
\hline Implications & Frequency & Percentage (\%) \\
\hline Increase in Traffic Problems & 152 & 36 \\
Decrease in housing Stock & 143 & 34 \\
Increase in Rental Value of Land use & 78 & 18 \\
Deterioration of the Quality of the Environment & 53 & 12 \\
Total & 426 & 100 \\
\hline
\end{tabular}

The aftermath of increase in population is urbanization which invariably leads to significant change in residential neighbourhoods and generate significant spillover effects to the growth in competing land uses. In Calabar, it is observed that land use changes have been sporadic due to improper planning and monitoring of the changing structure and widespread urbanization. However, a properly guided and effective land use change results in the highest and best use of land. The conversion of property from lower use to higher use results in a profitable investment and thus, favours the respective investors. This is a situation where existing land uses are changed to a superior use. Where this happens, the economic reality is that the net capital or rental value earn from the property is increased. The peaks are the higher property values which are reflected in clusters of complementarities activities along the major roads within the central business district in Calabar Municipality. There is also indication that commercial activities requiring spaces are able to pay higher rents and can favourably compete for strategic positions along choice routes. These categories of business activities are willing to pay higher rents as it is essential to their earning capacities. This is a good signal for property developers to invest in commercial properties as they have upward pressure on rents than residential properties which cannot compete with commercial properties in terms of returns, and are consequently push out from the ideal property market.

\section{Conclusion}

The study investigated the implications of changing land uses on physical environment in Calabar Municipality, Cross River State. The study revealed that different factors that influence changing land use in the area included condition of the road as well good access offered by the roads, increase in demand for commercial and public land uses, government policies, individual preferences and availability of infrastructures. The study revealed that problems such as traffic congestion, inadequate parking spaces, accidents, noise pollution and haphazard display of signposts/billboards were associated with changing land uses along major roads in the study area. The findings of this study agree with the findings of Okon (2008) that over concentration of vehicles and commercial activities have great implications on intra-city and environmental quality in terms of noise pollution, accidents, safety, security and aesthetics. Based on the findings, the study recommends the following: closure of land uses that do not have adequate parking space, embarking on land use and transportation studies particularly in areas where these changes are common, monitoring the changes in land use along affected roads in order to give a vivid 
picture of the changes over time, sitting and display of billboards and signposts should be subjected to the approval of the Municipal Planning Authority

\section{References}

Adebayo, M.O. (2009). Impact of Urban Land Use Changes on Property Values in Metropolitan Lagos. Medwell Journals, 4 (1): 111 - 117.

American Institute of Real Estate Appraisal (1994). Appraising Residential Properties, Chicago.

An, G. (2005). Three Essays on the Impact of Land Use Regulations and Land Development. Doctoral Dissertations at West Virginia University.

Ball, M., Lizieri, C. and McGregor, D. (1998). The Economic of Commercial Property Markets.Routlegde, London.

Barlowe, R. (1978). Land Resources Economics. Prentice Hall, USA

Bartlett, J.E., Kotrlik, J.W. and Higgins, C. C. (2001). Organizational Research: Deferring Appropriate Sample Size in Survey Research. Information Technology, Learning and Performance Journal, 19(1): 43.

Egbenta, I.R. (2011). Analysis of Residential Land Use Change in Enugu Urban. In Proceedings of the National Conference on Urban Planning and Environmental Issues in the Nigerian Context: From Theory to Practice. Dept of Urban \& Regional Planning, University of Nigeria, Enugu Campus.

Garrison, W.L. and Deakin, N. (1992). Land use and Public Transportation. 2nd ed., New Jersey: Prentice Hall, p. 39.

Hill, R.D. (1989). Land use Change. Proceeding of the Asahikawa-
Sapporo International Symposium, Hong Kong University Press, p. 112.

Ima, A.E. (2008). Spatial Analysis of Location Decision of Major Projects in Calabar Metropolis, Unpublished MURP Dissertation, University of Uyo, Uyo, Nigeria.

Lambin, E.F., Geist, H.J. and Lepers, E. (2003). Dynamics of Land-use and Land-cover Change in Tropical Regions. Annual Reviews of Environmental Resource. pp. 205 211.

Lean, W. (1969). Economics of Land Use Planning. Estate Gazette, London.

Lee, Y. (1974). A Conceptual Discussion and an Empirical Analysis of Commercial Land Use Succession. Environment and Planning, A6(6): $655-674$

Winger, A.R. (1977). Urban Economics, An Introduction. Charles E. Merril Publishing, London

Oduwaye, L. (2013). Urban Planning Implications of Changing Land Use Structure of Metropolitan Lagos, Nigeria. In: Proceedings Real Corp 2013, Tagungsband, Rome, Italy. Available at http://www.corp.at.Accessed on May, 232013.

Okon, I.E. (2008). Intra-city Transportation and Land use Planning in Nigeria: The case of Port Harcourt Metropolis. River State. Unpublished Ph.D Research Thesis Department of Geography and Regional Planning. University of Calabar, Calabar. Nigeria.

Turner, B.L. and Meyer, B.L. (1994). Global Land Use and Land Cover Change: An Overview. In: Meyer W. B. (Ed.), Changes in Land Use and Land Cover: A Global Perspective, 
Cambridge, Cambridge University Press, pp. 89 - 91.

Udoudoh, F.P., Umoren, V. and Ofem, B. (2011). Urban Renewal and Implications on Property Values in Uyo, Nigeria. Journal of Environmental Design, 6(2): 170 175.
Udoudoh, F.P. (2016). Real Estate and Infrastructure Economics in Urban Nigeria.MEF Nig. Ltd, Uyo, Nigeria.

Umeh, J.A. (1983). Compulsory Acquisition of Land and Compensation in Nigeria. Sweet and Maxwell, London 